\title{
PENGARUH ORIENTASI BELANJA DAN PERBEDAAN GENDER TERHADAP PENCARIAN INFORMASI ONLINE DAN BELANJA ONLINE PADA MAHASISWA JURUSAN ADMINISTRASI NIAGA POLITEKNIK NEGERI MALANG
}

\author{
Dwi Sudjanarti ${ }^{1}$, Umi Khabibah ${ }^{2}$, Tri Istining Wardani ${ }^{3}$ \\ 1,2,3 Politeknik Negeri Malang \\ dwisujanarti@polinema.ac.id ${ }^{1}$, umik01@polinema.ac.id², triist@polinema.ac.id ${ }^{3}$
}

(Artikel diterima: Mei 2020, diterima untuk terbit: Juni 2020)

\begin{abstract}
Abstrak - Penelitian ini bertujuan untuk mengetahui pengaruh orientasi belanja terhadap pencarian informasi online dan belanja online, serta perbedaan laki-laki dan perempuan dalam orientasi belanja. Jenis penelitian yang digunakan dalam penelitian ini adalah penelitian kuantitatif dengan jenis deskriptif kausal. Populasi penelitian adalah mahasiswa Jurusan Administrasi Politeknik Negeri Malang Tahun Akademik 2017/2018 yang pernah melakukan pembelian online. Pengumpulan data menggunakan kuesioner kepada 94 responden menggunakan teknik purposive random sampling. Analisis data menggunakan regresi sederhana untuk mengetahui pengaruh orientasi belanja terhadap pencarian informasi online dan belanja online, kemudian dilanjutkan dengan uji independent sample $\mathrm{T}$ test untuk melihat perbedaan laki-laki dan perempuan dalam orientasi belanja. Hasil penelitian menunjukkan bahwa orientasi belanja tidak berpengaruh terhadap pencarian informasi online dengan $\mathrm{t}$ hitung $0,547<\mathrm{t}$ tabel 1,66159. Orientasi belanja berpengaruh terhadap belanja online dengan $\mathrm{t}$ hitung 2,609 >t tabel 1,66159. Persamaan regresi sederhana yang didapatkan yaitu $\mathrm{Y} 1=7,898+0,013 \mathrm{X}$ dan $\mathrm{Y} 2=$ $2,492+0,082 \mathrm{X}$. Hasil penelitian menunjukkan bahwa tidak ada perbedaan orientasi belanja atara laki-laki dan perempuan.
\end{abstract}

Kata-kata kunci: orientasi belanja, pencarian informasi online, belanja online

\section{Pendahuluan}

Perkembangan teknologi dan internet yang semaikin pesat juga diikuti oleh perkembangan bisnis e-commerce atau online shop. Kebebasan setiap orang untuk mengakses internet, menjadikan online shop dengan mudah berkembang pada kalangan masyarakat modern. Perkembangan pengguna internet secara signifikan mempengaruhi bisnis online di Indonesia terlihat dari data forum jual beli terbesar di indonesia yang semakin bertambah jumlah membernya (Marindi, 2015).

Sistem berbelanja saat ini sudah memiliki beragam bentuk. Dalam hal ini cara dalam mendapatkan produk yang diinginkan seperti berbelanja secara online maupun berbelanja secara langsung (Ibrahim dalam Sihotang, 2009). Kegiatan belanja online merupakan cara baru dalam melakukan transaksi. Dalam kegiatan ini pembeli dan penjual tidak bertemu secara langsung seperti halnya proses penjualan biasa. Efisiensi waktu dan juga efektivitas dalam proses transaksi merupakan hal yang membuat konsumen tertarik untuk melakukan belanja online. Penjual menggunakan internet untuk menampilkan situs yang mereka miliki sebagai toko dengan segala produk yang ditawarkan kepada konsumen. Kemudian konsumen sebagai pembeli juga akan melihat dan memutuskan untuk membeli produk yang ditawarkan melalui situs yang ada (Ishak, 2012). Layanan tersebut dapat memudahkan konsumen dalam berbelanja. Konsumen tidak harus mendatangi toko atau tempat yang menjual barang-barang yang dibutuhkan oleh konsumen.

Dalam kegiatan belanja online, faktor jenis kelamin (gender) dapat mempengaruhi kegiatan belanja. Meskipun di jaman globalisasi sekarang ini kesetaraan gender selalu dijunjung tinggi oleh masyarakat, bahkan pria dan wanita dianggap memiliki kemampuan yang sama dalam memutuskan berbelanja online, tapi dalam beberapa penelitian menunjukkan bahwa gender merupakan faktor penting yang dapat mempengaruhi konsumen dalam perilaku belanja secara online (Prabowo dan Suwarsi, 2009). Dalam sebuah penelitian, ditemukan bahwa terdapat perbedaan jumlah produk atau jasa yang dibeli secara online antara pembeli pria dan wanita (Leonard dalam Lim et al, 2010). Gender dikatakan merupakan faktor yang membedakan frekuensi pembelian online (Wells dan Chen dalam Prabowo dan Suwarsi, 2009). Selanjutnya dalam penelitian yang dilakukan Prabowo dan Suwarsi (2009), juga terdapat perbedaan dimensi shopping orientation, online search information, dan online purchase antara pria dan wanita.

Sebelum konsumen melakukan pembelian, seperti biasa mereka sebelumnya akan mencari informasi mengenai produk yang diinginkannya, ataupun produk yang sedang ditawarkan oleh penjual. Bagi konsumen online, pencarian informasi tersebut bisa didapat melalui search engine di internet, atau dengan berkeliling keluar masuk toko online. Informasi yang dikumpulkan bisa berupa harga, merek, spesifikasi barang, bentuk, bahan material, dan lain-lain yang selanjutkan dijadikan bahan pertimbangan konsumen untuk melakukan pembelian. Mujiyana dan Ingge (2013) mendefinisikan proses belanja online adalah pencarian informasi, membandingkan alternatif yang ada, dan pengambilan keputusan. Dalam pengambilan keputusan belanja online, pencarian informasi lebih banyak dilakukan melalui media internet seperti menggunakan search engine atau toko online. Informasi yang dicari dapat berupa opini dari orang yang telah merasakan dampak langsung dalam menggunakan produk atau jasa yang tersedia di toko online. 


\section{A. Rumusan Masalah}

Penelitian ini akan mengukur pengaruh orientasi belanja terhadap pencarian informasi online dan belanja online. Dalam penelitian ini, peneliti juga akan meneliti apakah terdapat perbedaan orientasi belanja antara pria dan wanita. Berdasarkan uraian tersebut, maka permusan masalah dari penelitian ini adalah sebagai berikut:

1. Apakah orientasi belanja berpengaruh terhadap pencarian informasi online?

2. Apakah orientasi belanja berpengaruh terhadap belanja online?

3. Apakah terdapat perbedaan orientasi belanja antara lakilaki dan perempuan?

\section{B. Tujuan Penelitian}

Berdasarkan rumusan masalah yang diuraikan peneliti, maka tujuan dari penelitian ini adalah:

1. mengetahui pengaruh orientasi belanja terhadap pencarian informasi online.

2. mengetahui pengaruh orientasi belanja terhadap belanja online.

3. mengetahui perbedaan orientasi belanja antara laki-laki dan perempuan.

\section{Tinjauan Pustaka}

\section{A. Kajian Empiris}

Hasil penelitian terdahulu yang menjadi rujukan dalam penelitian ini adalah:

1. Tulay Girard Pradeep Korgaonkar dan Ronnie Silverblatt (2003) dengan judul "Relationship of Type of Product, Shopping Orientations, and demographics With Preference for Shopping on The Internet". Hasil penelitian ini menunjukkan bahwa Shopping Orientations berpengaruh positif terhadap pembelian produk pakaian dan parfum. Perbedaan gender berpengaruh dalam pembelian produk online dimana pembeli pria lebih banyak melakukan belanja online untuk produk telepon seluler, sedangkan pembeli wanita lebih banyak melakukan pembelian produk pakaian dan parfum.

2. Yoo-Kyoung Seock and Lauren R. Bailey (2008) pada penelitian yang berjudul "The influence of college students' shopping orientations and gender differences on online information searches and purchase behaviours", hasil penelitian menunujkkan bahwa tujuh indikator yang mewakili orientasi belanja berpengaruh secara signifikan terhadap pencarian informasi secara online dan perilaku pembelian (belanja online).

\section{B. Pemasaran}

Kotler dan Keller (2007) menjelaskan dua jenis pemasaran yakni pemasaran langsung dan pemasaran online. Pemasaran langsung didefinisikan sebagai komunikasi langsung dengan konsumen perorangan yang menjadi sasaran dengan tujuan untuk memperoleh tanggapan yang segera. Sedangkan pemasaran online dilakukan melalui sistem komputer online yang menghubungkan pelanggan dengan penjual secara elektronik

\section{Electronic Commerce (E-Commerce)}

Menurut Kotler \& Keller (2012) e-commerce merupakan pemanfaatan website dengan dukungan internet sebagai sarana menjual produk maupun jasa. Dengan tidak adanya biaya sewa tempat untuk usaha, pemanfaatan website dapat mendatangkan keuntungan dengan menjual produk dengan kuantitas tertentu pada pangsa pasar khusus. Menurut Hidayat (2013) e-Commerce adalah bagian dari e-lifestyle yang memungkinkan transaksi jual-beli dilakukan secara online dari sudut tempat dimanapun. Terdapat empat kategori dalam istilah e-commerce (Bearden et al., 2001), yaitu:

1. Bussiness to Customer (B2C), pelaku bisnis melakukan penjualan barang dan jasa kepada konsumen akhir.

2. Business to Business $(B 2 B)$, melibatkan penjualan produk dan layanan antar perusahaan.

3. Consumer to Consumer $(C 2 C)$, konsumen dapat melakukan transaksi jual beli atau pertukaran informasi barang atau jasa secara langsung dengan konsumen lainnya, melibatkan konsumen yang menjual secara langsung ke konsumen.

4. Consumer to Business $(C 2 B)$, konsumen individu menjual produk atau jasa kepada pelaku bisnis.

\section{Orientasi Belanja}

Orientasi belanja dikonsepkan sebagai bagian tertentu dari gaya hidup dan dijalankan oleh berbagai kegiatan, kepentingan dan pernyataan pendapat yang relevan dengan tindakan belanja (Li et al. dalam Kwek et al.,2010). Seock dan Bailey (2008) mengakui ada 7 orientasi belanja, yaitu:

1. Shopping enjoyment, pembeli pada segmen ini menikmati transaksi pembelian tidak hanya untuk produk yang dibeli, tetapi demi pengalaman itu sendiri.

2. Brand and fashion conscious shopper, mencari merekmerek terkenal dan lebih trendi.

3. Price conscious, adalah pembeli yang mencari harga produk yang lebih rendah.

4. Shopping confidence, adalah pembeli yang yakin pada kemampuan mereka untuk menjadi pembeli yang bijaksana.

5. Convenienceltime conscious, lebih mencari transaksi pembelian yang membuat mereka nyaman.

6. In-home shopping, adalah pembeli yang lebih suka berbelanja dari rumah.

7. Brand/store loyalty, merupakan segmen yang menujukkan para pembeli yang setia terhadap merek atau toko tertentu.

\section{E. Perbedaan Gender}

Oakley dalam Relawati dan Sukesi (2011) menyatakan gender adalah perbedaan kebiasaan atau tingkah laku antara laki-laki dan perempuan yang dikonstruksikan secara sosial, yang dibuat oleh laki-laki dan perempuan itu sendiri. Pria dan wanita menginginkan produk yang berbeda dan mereka memiliki jalan pikiran yang berbeda untuk mendapatkan produk atau barang yang mereka inginkan (Bakewell dan Mitchell,2003) 


\section{F. Pencarian Informasi Online}

Dalam proses pencarian informasi online, Chen (2009) membagi menjadi dua bagian, yaitu pencarian informasi dan evaluasi online, dan proses informasi online/pengalaman yang bermanfaat. Kegiatan mencari meliputi jumlah website yang dikunjungi oleh konsumen sebelum mereka melakukan pembelian, jenis situs web pencarian, frekuensi browsing online, jumlah pencarian, dan penggunaan istilah pencarian atau kata kunci (Ahuja et al dalam Lim et al, 2010).

\section{G. Belanja Online}

Online shopping atau biasa juga disebut internet shopping atau internet buying merupakan proses dari pembelian produk atau jasa melalui internet (Prabowo dan Suwarsi, 2009). Aktivitas belanja dapat diukur dari jumlah waktu yang dihabiskan selama berbelanja, frekuensi berbelanja, dan jumlah uang yang dikeluarkan dalam berbelanja (Magie, 2008). Seperti belanja di toko biasa, sebelum melakukan belanja online, seorang konsumen juga dapat mencari dan membandingkan produk atau jasa yang sesuai dengan keinginan dan kemampuan konsumen tersebut. Namun bedanya, dalam belanja online juga menggunakan fasilitas internet dalam pencarian informasi mengenai produk yang diinginkannya.

\section{H. Hipotesis Penelitian}

Pada penelitian ini digunakan tujuh indikator untuk mengukur variabel bebas yang terkait dalam orientasi belanja (X). Sedangkan variabel terikat adalah pencarian informasi online $\left(\mathrm{Y}_{1}\right)$ dan belanja online $\left(\mathrm{Y}_{2}\right)$. Pengujian hipotesis penelitian dilakukan dalam 3 tahap:

1. regresi sederhana dengan pencarian informasi online sebagai variabel dependen $\left(\mathrm{Y}_{1}\right)$, dan variabel independen orientasi belanja $(\mathrm{X})$.

2. regresi sederhana dengan belanja online sebagai variabel dependen $\left(\mathrm{Y}_{2}\right)$, dan variabel independen orientasi belanja $(\mathrm{X})$.

3. pengujian hipotesis untuk mengetahui ada tidaknya perbedaan orientasi belanja (X) antara laki-laki dan perempuan, pengujian ini dilakukan dengan menggunakan uji beda Independent Sample T Test.

Hipotesis adalah dugaan sementara yang perlu dibuktikan kebenarannya. Berdasarkan paradigma penelitian di atas, maka dapat dirumuskan hipotesis penelitian, yaitu:

$\mathrm{H}_{1}$ : Diduga terdapat pengaruh signifikan antara variabel orientasi belanja terhadap pencarian informasi online.

$\mathrm{H}_{2}$ : Diduga terdapat pengaruh signifikan antara variabel orientasi belanja terhadap belanja online.

$\mathrm{H}_{3}$ : Diduga terdapat perbedaan orientasi belanja antara laki-laki dan perempuan.

\section{Metodologi}

\section{A. Jenis Penelitian}

Jenis penelitian yang digunakan dalam penelitian ini adalah penelitian kuantitatif dengan jenis deskriptif kausal. Pada pendekatan penelitian kuantitatif, data penelitian hanya akan dapat diinterpretasikan dengan lebih objektif apabila diperoleh lewat suatu proses pengukuran disamping valid dan reliabel, juga objektif (Azwar, 2008). Hubungan kausal menurut Sugiyono (2013) merupakan hubungan yang bersifat sebab akibat dimana ada variabel independen (variabel yang mempengaruhi) dan dependen (dipengaruhi).

\section{B. Populasi dan Sampel}

Populasi menurut Sugiyono (2013) merupakan wilayah generalisasi yang terdiri atas, objek/subjek yang mempunyai kualitas dan karakteristik tertentu yang ditetapkan oleh peneliti untuk dipelajari dan kemudian ditarik kesimpulannya. Populasi dalam penelitian ini adalah Mahasiswa Jurusan Administrasi Niaga Politeknik Negeri Malang Tahun Akademik 2018/2019 sejumlah 1.453 mahasiswa.

Sampel merupakan sebagian atau wakil dari populasi yang memiliki sifat dan karakter yang sama serta memenuhi populasi yang diselidiki, Sugiyono (2013). Pengambilan sampel dengan mengacu pada pendapat solvin, dengan jumlah responden sebanyak 94 mahasiswa.

\section{Teknik Sampling}

Teknik pengambilan sampel pada penelitian ini menggunakan teknik purposive random sampling. Purposive sampling termasuk dalam metode non probability sampling (Sugiyono, 2014). Definisi metode purposive sampling menurut Sugiyono (2013) adalah: "Teknik penentuan sampel dengan pertimbangan tertentu". Pertimbangan tersebut didasarkan pada kepentingan dan tujuan penelitian (Suharyadi dan Purwanto, 2004). Sesuai dengan tujuan penelitian, syarat untuk menjadi responden dalam penelitian ini yaitu mahasiswa jurusan Administrasi Niaga Politeknik Negeri Malang Tahun Akademik 2018/2019 laki-laki atau perempuan yang pernah melakukan pembelian online, minimal satu kali.

\section{Metode Pengumpulan Data}

Teknik pengumpulan data dalam penelitian ini menggunakan kuesioner. Kuesioner merupakan metode pengumpulan data dengan mengajukan pertanyaan tertulis yang disusun secara sistematis kepada responden. Kuesioner adalah teknik pengumpulan data yang dilakukan dengan cara memberi seperangkat pertanyaan tertulis kepada responden untuk dijawab (Sugiyono, 2013). Sedangkan kriteria pengukuran skala likert adalah $1=$ Sangat Tidak Setuju, 2 = Tidak Setuju, 3 = Ragu/Agak Setuju, 4 = Setuju, $5=$ Sangat Setuju.

\section{E. Definisi Operasional Variabel Penelitian}

Operasional variabel penelitian adalah sebuah konsep yang mempunyai variasi nilai yang diterapkan dalam suatu penelitian. Berikut ini adalah variabel-variabel yang akan diteliti, yaitu :

Tabel 3.1. Operasional Variabel Penelitian

\begin{tabular}{|c|c|c|}
\hline Variabel & Indikator & Item \\
\hline Orientasi & Shopping & Senang \\
\hline
\end{tabular}




\begin{tabular}{|c|c|c|}
\hline \multirow{13}{*}{$\begin{array}{c}\text { Belanja } \\
\text { (Seock dan } \\
\text { Bailey, 2008) }\end{array}$} & \multirow[t]{3}{*}{ Enjoyment } & Menikmati \\
\hline & & menghabiskan waktu \\
\hline & & proses mudah \\
\hline & \multirow{3}{*}{$\begin{array}{c}\text { Brand/ } \\
\text { fashion } \\
\text { Conscious }\end{array}$} & $\begin{array}{l}\text { merek produk yang } \\
\text { sudah dikenal }\end{array}$ \\
\hline & & bebas memilih. \\
\hline & & trend merek \\
\hline & \multirow{4}{*}{$\begin{array}{c}\text { Price } \\
\text { Conscious }\end{array}$} & harga \\
\hline & & penawaran promosi \\
\hline & & perbandingan harga \\
\hline & & menghemat uang \\
\hline & \multirow{3}{*}{$\begin{array}{c}\text { Shopping } \\
\text { Confidenc } \\
e\end{array}$} & Percaya diri \\
\hline & & $\begin{array}{l}\text { membeli produk yang } \\
\text { tepat }\end{array}$ \\
\hline & & $\begin{array}{l}\text { Berpikir sebagai } \\
\text { pembelanja yang baik }\end{array}$ \\
\hline & \multirow{3}{*}{$\begin{array}{l}\text { Conveni- } \\
\text { encel time } \\
\text { conscious }\end{array}$} & Hemat waktu \\
\hline & & $\begin{array}{l}\text { tidak mengganggu } \\
\text { aktivitas lain }\end{array}$ \\
\hline & & $\begin{array}{l}\text { dapat dilakukan kapan } \\
\text { saja. }\end{array}$ \\
\hline & \multirow[t]{2}{*}{$\begin{array}{l}\text { In-home } \\
\text { shopping }\end{array}$} & $\begin{array}{l}\text { tidak perlu keluar } \\
\text { rumah }\end{array}$ \\
\hline & & $\begin{array}{l}\text { dapat dilakukan } \\
\text { dimana saja }\end{array}$ \\
\hline & \multirow[t]{2}{*}{$\begin{array}{l}\text { Brand/ } \\
\text { store } \\
\text { Loyalty }\end{array}$} & $\begin{array}{l}\text { Pembelian ulang pada } \\
\text { toko/merek yang } \\
\text { sama }\end{array}$ \\
\hline & & $\begin{array}{l}\text { Tidak berpindah toko } \\
\text { atau merek ketika } \\
\text { terjadi perubahan } \\
\text { harga }\end{array}$ \\
\hline \multirow{2}{*}{$\begin{array}{l}\text { Pencarian } \\
\text { Informasi } \\
\text { online (Chen, } \\
\text { Chun-An, } \\
\text { 2009) }\end{array}$} & $\begin{array}{l}\text { informasi } \\
\text { produk }\end{array}$ & $\begin{array}{l}\text { pengetahuan tentang } \\
\text { produk }\end{array}$ \\
\hline & $\begin{array}{l}\text { harga } \\
\text { produk }\end{array}$ & $\begin{array}{l}\text { pengetahuan } \\
\text { mengenai harga } \\
\text { produk }\end{array}$ \\
\hline \multirow{2}{*}{$\begin{array}{l}\text { Belanja } \\
\text { Online } \\
\text { (Kim et al., } \\
\text { 2000) }\end{array}$} & $\begin{array}{l}\text { Pengeluar } \\
\text { an }\end{array}$ & Jumlah uang \\
\hline & Frekuensi & $\begin{array}{l}\text { Frekuensi belanja } \\
\text { online }\end{array}$ \\
\hline
\end{tabular}

Sumber: Seock dan Bailey,(2008), Chen, Chun-

An, (2009), Kim et al., (2000)

\section{F. Metode Analisis Data}

\section{1) Uji Validitas}

Uji Validitas data adalah pengujian yang dilakukan guna untuk mengetahui seberapa cermat suatu instrument dalam mengukur apa yang ingin diukur (Priyatno, 2010). Pengujian validitas dilakukan dengan cara mengkorelasikan jumlah skor faktor dengan skor total. Bila korelasi tiap faktor tersebut positif dan besarnya > 0,3 maka faktor tersebut dinyatakan valid, Sebaliknya jika korelasi tiap faktor tersebut negatif dan besarnya < 0,3 maka faktor tersebut dinyatakan tidak valid (Sugiyono, 2013).

\section{2) Uji Realibilitas}

Uji reliabilitas (keandalan) merupakan ukuran suatu kestabilan dan konsistensi responden dalam menjawab hal yang berkaitan dengan konstruk-konstruk pertanyaan yang merupakan dimensi suatu variabel dan disusun dalam bentuk kuesioner. Instrumen dikatakan reliabel atau handal jika jawaban seseorang terhadap pertanyaan adalah konsisten atau stabil dari waktu ke waktu. Uji reliabilitas digunakan untuk mengukur bahwa variabel yang digunakan benarbenar bebas dari kesalahan sehingga menghasilkan hasil yang konstan meskipun diuji beberapa kali. Suatu alat ukur dapat dianggap reliabel apabila nilai cronbach alpha yang diperoleh $=0,60$. Untuk mendapatkan hasil uji tersebut digunakan alat bantu program SPSS.

\section{G. Analisis Regresi Sederhana}

Analisis ini dilakukan untuk meneliti adanya pengaruh antara variabel independen orientasi belanja $(\mathrm{X})$ terhadap variabel dependen yaitu pencarian informasi online $\left(\mathrm{Y}_{1}\right)$ dan belanja online $\left(\mathrm{Y}_{2}\right)$. Adapun persamaan yang digunakan adalah sebagai berikut :

Dimana:

$$
\begin{aligned}
& Y_{1}=a+b X \\
& Y_{2}=a+b X
\end{aligned}
$$

$\mathrm{Y}_{1} \quad$ : Pencarian Informasi Online

$\mathrm{Y}_{2} \quad$ : Belanja Online

$\mathrm{X}$ : Orientasi Belanja

a : konstanta

b $\quad$ : Koefisien regresi

\section{H. Analisis Koefisien Determinasi $\left(R^{2}\right)$}

Pada regresi sederhana nilai koefisien determinasi $\left(\mathrm{R}^{2)}\right.$ digunakan untuk mengetahui persentase pengaruh variabel independen terhadap perubahan variabel dependen. (Algifari, 2007).

\section{Uji Hipotesis (Uji t)}

Uji parsial pada dasarnya menunjukkan seberapa jauh pengaruh suatu variabel independen secara individual dalam menerangkan variasi variabel dependen (Ghozali,2013). Metode pengujian terhadap hipotesis yang diajukan, dilakukan dengan menggunakan uji t. Kriteria pengujian di dalam uji t dapat dijabarkan sebagai berikut :

a. jika $\mathrm{t}(\operatorname{sig})<(\operatorname{Sig} \alpha=0,05)$ maka Ho ditolak dan $\mathrm{Ha}$ diterima, berarti variabel bebas (X) secara parsial mempunyai pengaruh terhadap variabel terikat (Y).

b. Jika $t_{\text {hit }}>t_{\text {tabel }}$ maka Ho ditolak dan Ha diterima, berarti variabel bebas $(\mathrm{X})$ secara parsial mempunyai pengaruh terhadap variabel terikat (Y).

\section{J. Independen sample T test}

Independen sample $T$ test atau uji sampel bebas digunakan untuk menguji perbedaan rata-rata dari dua kelompok data atau sampel yang independen. Dalam penelitian ini, pengujian sampel bebas ini dilakukan untuk mengetahui apakah ada perbedaan orientasi belanja antara mahasiswa laki-laki dan perempuan.

\section{Pembahasan}

\section{A. Uji Validitas}

Berdasarkan perhitungan uji validitas menunjukkan bahwa masih terdapat pernyataan pernyataan dari variabel Orientasi Belanja (X) tidak valid, maka pernyataan tersebut 
tidak dapat digunakan atau dihilangkan dari daftar pernyataan dalam kuesioner.

\section{B. Uji Reliabilitas}

Uji reliabilitas diketahui melalui hasil uji SPSS menunjukkan bahwa terdapat beberapa pernyataan untuk variabel Orientasi Belanja (X) yang tidak reliabel maka pernyataan tersebut tidak dapat digunakan atau dihilangkan dari daftar pernyataan dalam kuesioner. Dengan demikian pernyataan yang digunakan dalam penelitian ini untuk variabel Orientasi Belanja (X) sebanyak 15 pernyataan yang reliabel dan dapat dijadikan sebagai alat ukur.

\section{Analisa Regresi Berganda}

Berdasarkan hasil analisis regresi sederhana tersebut, maka didapat hasil persamaan sebagai berikut :

$\mathrm{Y}_{1}=7,898+0,013 \mathrm{X}$

$\mathrm{Y}_{2}=2,492+0,082 \mathrm{X}$

Berdasarkan persamaan regresi linier berganda diatas dapat dijelaskan sebagai berikut:

1. Konstanta $\mathrm{a}=7,898$ untuk persamaan $\mathrm{Y}_{1}$ artinya jika orientasi belanja (X) diasumsi nol maka variabel pencarian informasi online $\left(\mathrm{Y}_{1}\right)$ akan sebesar nilai konstantanya yaitu 7,898.

2. Konstanta $\mathrm{a}=2,492$ untuk persamaan $\mathrm{Y}_{2}$ artinya jika orientasi belanja $(\mathrm{X})$ diasumsi nol maka variabel belanja online $\left(\mathrm{Y}_{2}\right)$ akan sebesar nilai konstantanya yaitu 2,492.

3. Koefisien regresi $b$ variabel orientasi belanja $=0,013$; artinya jika variabel orientasi belanja naik satu satuan, jadi besarnya kontribusi orientasi belanja terhadap variabel pencarian informasi online meningkat sebesar 0,013 .

4. Koefisien regresi b variabel orientasi belanja $=0,082$; artinya jika variabel orientasi belanja naik satu satuan, jadi besarnya kontribusi orientasi belanja terhadap variabel belanja online meningkat sebesar 0,082 .

\section{Koefisien Determinasi}

Berdasarkan tabel di atas bahwa angka $\mathrm{R}^{2}$ adalah sebesar 0,003 untuk pencarian informasi online $\left(\mathrm{Y}_{1}\right)$, sehingga dapat dikatakan bahwa korelasi atau keeratan hubungan variabel orientasi belanja $(\mathrm{X})$ dengan pencarian informasi online $\left(\mathrm{Y}_{1}\right)$ adalah sangat lemah. Tabel di atas juga menunjukkan $\mathrm{R}^{2}$ adjusted adalah sebesar -0,008, maka besarnya pengaruh variabel orientasi belanja terhadap pencarian informasi online adalah sebesar $8 \%$ sedangkan $92 \%$ dipengaruhi oeh faktor lain diluar penelitian.

\section{E. Ujit}

Hasil perhitungan SPSS grafik untuk mengetahui hasil uji hipotesa ada tidaknya pengaruh orientasi belanja terhadap pencarian informasi online dan belanja online adalah sebagai berikut:

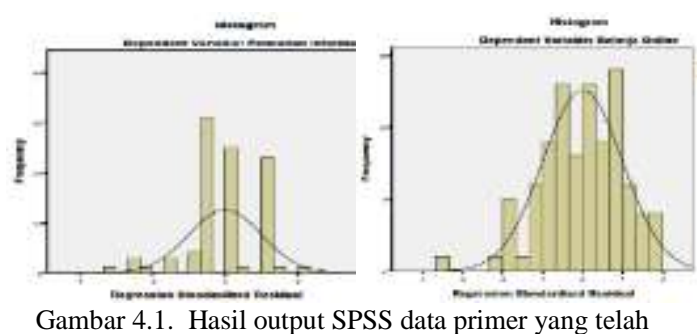

Dari tabel koefisien diperoleh nilai $\mathrm{t}$ hitung sebesar 0,547 dan nilai t tabel $(\alpha=0,05)$ sebesar 1,66159. Dengan membandingkan antara thitung dan t tabel maka ditemukan bahwa t hitung 0,547 berada diantara -1,66159 dan 1,66159, maka dapat disimpulkan bahwa Ho diterima dan Ha ditolak. Demikian juga hasil yang diperoleh dari perbandingan nilai sig. dengan taraf signifikansi yaitu sig. a $=0,585>0,05$, maka dapat disimpulkan bahwa Ho diterima dan Ha ditolak. Ini menunjukkan bahwa koefisien regresi pada variabel orientasi belanja (X) tidak signifikan. Artinya orientasi belanja $(\mathrm{X})$ tidak berpengaruh terhadap pencarian informasi Online $\left(\mathrm{Y}_{1}\right)$.

Dari tabel koefisien diperoleh nilai $\mathrm{t}$ hitung sebesar 2,609 dan nilai t tabel $(\alpha=0,05)$ sebesar 1,66159. Dengan membandingkan antara $t$ hitung dan t tabel maka ditemukan bahwa t hitung 2,609 > t tabel 1,66159, maka dapat disimpulkan bahwa Ho ditolak dan Ha diterima. Demikian juga hasil yang diperoleh dari perbandingan nilai sig. dengan taraf signifikansi yaitu sig. $a=0,011<0,05$, maka dapat disimpulkan bahwa Ho ditolak dan Ha diterima. Ini menunjukkan bahwa koefisien regresi pada variabel orientasi belanja (X) signifikan. Artinya orientasi belanja (X) berpengaruh terhadap belanja online $\left(\mathrm{Y}_{2}\right)$.

\section{F. Independent sample T test}

Hasil uji independent sample T test digunakan untuk menguji perbedaan orientasi belanja antara mahasiswa lakilaki dan perempuan.

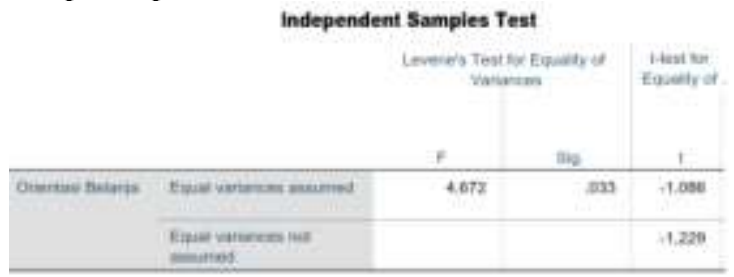

Gambar 4.2. Hasil Running SPSS

Berdasarkan tabel di atas diperoleh nilai $\mathrm{t}$ hitung sebesar -1,086, sementara nilai t tabel pada penelitian ini adalah 1,66159. Dengan membandingkan antara t hitung dan $\mathrm{t}$ tabel maka ditemukan bahwa t hitung berada diantara 1,66159 dan +1,66159, maka dapat disimpulkan bahwa Ho diterima dan Ha ditolak. Ini menunjukkan bahwa tidak terdapat perbedaan orientasi belanja antara responden lakilaki dan perempuan.

Dalam penelitian ini baik responden laki-laki maupun perempuan memiliki orientasi belanja yang sama dalam kegiatan belanja melalui internet. Hasil penelitian ini berbeda dengan beberapa penelitian terdahulu yang dilakukan di Amerika, yang menyatakan bahwa terdapat perbedaan yang signifikan terhadap orientasi belanja antara pria dan wanita. Adanya perbedaan hasil tersebut dikarenakan adanya perbedaan budaya antara negaraIndonesia dan Amerika. Mereka menyatakan bahwa 
di negara Amerika sudah terjadi pergeseran peranan antara pria dan wanita yang menjadikan perbedaan perilaku belanja antara pria dan wanita. Berbeda dengan di Indonesia, di mana pergeseran peranan tersebut belum bergeser, sehingga menyebabkan perilaku belanja antara pria dan wanita Indonesia masih terbilang sama. Berdasarkan argumentasi tersebut, maka perbedaan hasil dalam penelitian ini dengan hasil dalam penelitian terdahulu, juga dikarenakan adanya perbedaan faktor sosial dan budaya antar negara yang berbeda, yang kemudian mempengaruhi perbedaan perilaku belanja antara pria dan wanita di Indonesia dan Amerika.

\section{Penutup}

\section{A. Simpulan}

Berdasarkan hasil analisis data dan pembahasan yang telah dilakukan pada bab sebelumnya mengenai pengaruh orientasi belanja dan perbedaan gender terhadap pencarian informasi online dan belanja online pada mahasiswa Jurusan Administrasi Niaga Politeknik Negeri Malang, maka kesimpulan yang dapat diambil yaitu:

1. Hasil persamaan regresi sederhana menyatakan bahwa korelasi atau keeratan hubungan variabel orientasi belanja $(\mathrm{X})$ dengan pencarian informasi online $\left(\mathrm{Y}_{1}\right)$ maupun dengan variabel belanja online $\left(\mathrm{Y}_{2}\right)$ adalah sangat lemah. Pengaruh variabel belanja online $(\mathrm{X})$ terhadap pencarian informasi online dan belanja online juga sangat kecil sebagaimana ditunjukkan dari nilai $\mathrm{R}^{2}$ adjusted.

2. Hasil perhitungan Uji t menunjukkan bahwa variabel orientasi belanja (X) tidak berpengaruh terhadap pencarian informasi Online $\left(\mathrm{Y}_{1}\right)$. Sedangkan hasil uji t terhadap variabel belanja online $\left(\mathrm{Y}_{2}\right)$ menunjukkan bahwa variabel orientasi belanja (X) berpengaruh terhadap belanja online $\left(\mathrm{Y}_{2}\right)$.

3. Hasil uji sampel bebas (Independent sample $T$ test) menunjukkan bahwa tidak terdapat perbedaan orientasi belanja antara responden laki-laki dan perempuan.

\subsection{Saran}

Berdasarkan pada hasil penelitian yang telah dilakukan maka dapat disarankan sebagai berikut:

1. Bagi para pihak yang baru akan membuka toko online, sebaiknya untuk lebih memperhatikan desain, layout dan penyampaian informasi sedetail mungkin mengenai kualitas produk, harga, cara pengiriman dan lain-lain yang sesuai dengan toko online yang dimilikinya. Sehingga konsumen atau calon konsumen yang berorientasi untuk belanja dapat lebih memanfaatkan pencarian informasi online.

2. Pihak toko online sebaiknya tetap menentukan target konsumennya, walaupun tidak ada perbedaan antara orientasi belanja laki-laki dan perempuan. Dikarenakan hal tersebut akan dapat memberikan pelayanan toko sesuai dengan kebutuhan para konsumennya untuk menarik lebih banyak jumlah pengunjung toko dan juga meningkatkan jumlah penjualannya.

3. Berdasarkan hasil analisis koefisien determinasi, pengaruh orientasi belanja (X) terhadap pencarian informasi online dan belanja online menunjukkan angka persentase yang relative kecil. Oleh karena itu untuk penelitian selanjutnya agar menambahkan beberapa variabel yang tidak peneliti masukkan dalam penelitian ini.

\section{RUJUKAN}

[1] Algifari, 2013. Analisis regresi: Teori, kasus dan solusi (ed.2), Yogyakarta, BPFE.

[2] Azwar, S., 2008. Penyusunan skala psikologi, Yogayakarta, Pustaka Pelajar.

[3] Bearden, et al, 2001. Marketing: Priciples and Perspectives $\left(3^{\text {rd }}\right.$ ed.), New York, Mc.Graw-Hill.

[4] Bakewell, Cathy and Mitchell, Vincent Wayne, 2003. Generation Y female consumer decision-making styles, International Journal of Retail \& Distribution Management, Volume 31.Number 2\# MCB UP Limited.2003 ISSN 09590552pp. 95-106 available at http://www.emeraldinsight. com/ researchregister

[5] Chen, Chun-An, 2009. Information-Oriented Online Shopping Behavior in Electric Commerce Environment, Journal of Software, vol. 4, No. 4.

[6] Ghozali, Imam, 2013. Aplikasi Analisis Multivariate Dengan Progam IBM SPSS 21, Edisi 5, Semarang, Universitas Diponegoro.

[7] Hidayat ,Wicaksono Surya., 2013. Orang Indonesia gemar berbagi belanja online, di akses pada 5 Juli 2018, http://tekno.kompas.com/read/2013/

05/04/14084839/orang.indonesia.gemar.quotberbagiquot.bela nja.online.

[8] Ishak, A., 2012. Analisis kepuasan pelanggan dalam belanja online sebuah studi tentang penyebab (antecedents) dan konsekuensi (consequents). Jurnal Siasat Bisnis, 16 (2).

[9] Korgaonkar, Tulay Girard Pradeep and Silverblatt, Ronnie, 2003. Relationship of Type of Product, Shopping Orientations and Demographics with Preference for Shopping in the Internet, Journal of Business and Psychology, Vol. 18, No.1. pp.101-120.

[10] Kotler, Philip and Keller,Kevin Lane, 2007. Manajemen Pemasaran, Edisi 11, Jilid 2, Jakarta, Penerbit Erlangga.

[11] Kotler, P., \& Keller, Kevin, L., 2012. Marketing management (14 th ed.). Harlow: Pearson Education, Inc.

[12] Kwek et al., 2010, Investigating the Shopping Orientations on Online PurchaseIntention in the e-Commerce Environment: A Malaysian Study, Journal of Internet Banking and Commerce, August, Vol.15, No.2, 2010, 1-22.

[13] Lim et al., 2010. Online Search and Buying Behavior: Malaysian Experience, Canadian Social Science, vol. 6, No.4.

[14] Magie, Anna Ashlock, 2008. An Analysis of Lifestyle, Shopping Orientations, Shopping Behaviors and Shopping Involvement Among Teens Aged 13 to 18 in The United States, ProQuest Dissertations and Theses.

[15] Marindi, N., 2015, Hubungan antara kepuasan konsumen dalam belanja dengan perilaku konsumtif pada mahasiswa psikologi universitas negeri Surabaya, Jurnal Online Universitas Negeri Surabaya 03 (2).

[16] Mujiyana dan Ingge Elisaa, 2013. Analisis Faktor-faktor Yang Mempengaruhi Keputusan Pembelian Via Internet Pada TokoOnline, Depok, Jurnal Manajemen Vol 8, Universitas Gunadarma.

[17] Prabowo dan Suwarsi,2009, Pengaruh Shopping Orientations dan Gender Differences pada Online Information Search dan Online Purchase, Fokus Manajerial, Vol. 7, No. 2, 2009.

[18] Priyatno, Duwi, 2010. Teknik Mudah dan Cepat Melakukan Analisis Data Penelitian Dengan SPSS, Yogyakarta, Penerbit Gaya Media.

[19] Relawati dan Sukesi, 2011. Konsep dan Aplikasi Penelitian Gender, Bandung, CV. Mutiara Indah.

[20] Seock, Yoo-Kyoung., \& Bailey, Lauren R, 2008. The Influence of College Students' Shopping Orientation and 
Gender Difference on Online Information Searches and Purchase Behavior. Internation Journal of Consumer Studies, p. 113-121.

[21] Sihotang, 2009. Kepercayaan dan dampaknya terhadap kepuasan belanja online di Pekanbaru, Jurnal Ekonomi, Vol. 22, hal, 3

[22] Sugiyono, 2013. Metode Penelitisn Bisnis, Cetakan 17, Bandung, CV Alfabeta.

[23] Suharyadi dan Purwanto, 2004, Statistika untuk Ekonomi \& Keuangan Modern, Salemba Empat, Jakarta. 